\title{
Selawatan Sebagai Seni Pertunjukan Musikal
}

\author{
Andre Indrawan ${ }^{1}$ \\ Jurusan Musik, Fakultas Seni Pertunjukan ISI Yogyakarta.
}

\begin{abstract}
The Selawatan as Musical Performance. The selawatan, an Indonesian Islamic performing arts genre, has been looked at from different study perspectives. Although mostly understood as a group type of folk dances as well as theatres, this study has found that the selawatan in the DIY is closely related to an Islamic musical genre which was based on vocal art. The most important characteristic that relates amongst any types of selawatan is its repertoire materials which is centered to a classical Arabic text known as mawlid, especially the one that was written by $\mathrm{Al}$ Barzanji.
\end{abstract}

Key words: selawatan, mawlid, vocal art.

\section{Pendahuluan}

Selawatan berasal dari kata Arab, shalawah, yang diadopsi ke dalam kata Indonesia menjadi "selawat." Kata selawat dibubuhi akhiran "-an" guna menunjukkan berbagai kemasan aktivitas dalam bentuk seni pertunjukan bernafaskan Islam, yang setidaknya melibatkan bacaan selawat yang ditujukan untuk Nabi Muhammad SAW. Shalawah sendiri terbentuk dari kata dasar shalah yang kemudian diadopsi ke dalam bahasa Indonesia, yaitu "solat" atau "salat." Pengertian yang sebenarnya dari kata salat atau shalah, ialah "doa," yang dipahami secara umum sebagai ritual harian umat Islam, yaitu menyembah Tuhan Yang Maha Esa (Hidayah, 1989:126-133). Istilah "selawatan" tidak dikenal dalam lingkup internasional dunia Islam sehingga merupakan istilah umum pertunjukan Islami yang merupakan cirikhas kalangan Muslim Indonesia, khususnya masyarakat Jawa.

Walaupun peristilahan tersebut hanya dikenal di Indonesia bukan berarti bentuk-bentuk seni pertunjukan yang serupa dengan selawatan tidak terdapat di negara-negara Islam lain. Umumnya kesenian-kesenian yang memiliki landasan prinsip yang sama dengan selawatan di negaranegara tersebut dikenal dengan istilah mawlid atau disebut melvit di Turki. Kesenian-kesenian musikal tersebut didasarkan atas tradisi pembacaan karya-karya mawlid, yaitu gubahan prosa tentang kemuliaan akhlak serta riwayat kehidupan Nabi
Muhammad SAW. Dalam kenyataannya keseniankesenian tersebut memiliki bentuk yang bervariasi, dari hanya pembacaan teks secara musikal hingga kombinasi berbagai unsur seni lain seperti iringan instrumen, tari, dan gerak-gerak teatrikal. Di samping itu, unsur-unsur kesenian dan tradisi lokal juga turut mewarnai khasanah varietas seni mawlid di dunia Islam. Pembahasan dalam artikel ini meliputi tinjauan berbagai perspektif kajian tentang selawatan.

\section{Selawatan di Pesantren}

Selawatan diperkirakan berasal dari tradisi pesantren, yaitu sekolah-asrama anak-anak Islam di Jawa. Sejak awal penyebaran Islam di Indonesia bentuk penyajian mawlid yang asli, yaitu seni kelompok vokal (vocal group) relijius, hingga kini masih terpelihara dalam bentuk selawatan di lingkungan pesantren tradisional. Hal tersebut dapat dimaklumi mengingat pesantren, khususnya pesantren tradisional, adalah tempat belajar agama Islam yang mempertahankan model pembelajaran tradisional dengan materi-materi asli dari buku-buku klasik, yang dikenal dengan istilah 'buku kuning.' Seiring dengan itu tradisi seni membaca kitab-kitab mawlid berbahasa dan bertulisan Arab di pesantren tradisional yang kini secara umum disebut selawatan atau secara khusus disebut dengan berbagai nama yang dikaitkan dengan judul buku atau nama penulis mawlid yang dibaca, hingga kini masih terpelihara.

1 Alamat korespondensi: Prodi Musik, FSP ISI Yogyakarta, jalan Parangtritis Km. 6,5 Sewon, Bantul, Yogyakarta-55001. Email: indrawan_andre@yahoo.com. HP: +6281804251709 
Ketatnya peraturan-peraturan harian pesantren tradisional menyebabkan tradisi-tradisi yang diterapkan di dalamnya resistan terhadap pengaruh-pengaruh dari luar. Dalam kemandiriannya justru sebaliknya, pesantren memiliki kekuatan untuk mempengaruhi masyarakat di sekitarnya baik secara langsung maupun tidak langsung.

Dengan demikian tidaklah mengherankan jika tradisi selawatan pesantren terdapat juga di luar pesantren. Kondisi seperti inilah yang tampaknya mendasari asumsi bahwa hampir semua kesenian yang tergolong selawatan di luar pesantren tradisional di wilayah DIY, baik secara langsung maupun tidak senantiasa mengacu pada jenis selawatan pesantren. Repertoar-repertoar selawatan pesantren diadopsi masyarakat, baik dalam bentuk aslinya yang berbahasa Arab maupun kutipan bagian-bagiannya, ke dalam berbagai ragam seni pertunjukan rakyat.

Dalam penelitian dan upaya-upaya dokumentasi kebudayaan, keberadaan selawatan jarang digolongkan kepada seni musik namun lebih sering kepada kelompok seni tari atau sastra (lihat database Kelompok Seni Pertunjukan Dinas Kebudayaan DIY 2009). Penelitian terdahulu menunjukkan bahwa pengamat seni telah melihat selawatan berdasarkan perspektif disiplinnya masing-masing (lihat Djoharnurani, eds.,1994; Rachman, 1978-79; Sunaryadi, 1992; Soedarsono, eds, 1977-78; dan Iswantara, 2000). Tidaklah mengherankan jika selama ini berbagai bentuk seni pertunjukan selawatan di DIY teridentifikasi sebagai seni tari atau seni teater sehingga musik hanyalah diposisikan sebagai pengiring.

Kajian musikologis memandang selawatan sebagai seni musik, sementara seni-seni lain justru sebagai pengiringnya. Hal tersebut karena kedudukan syair dan pesan Islami adalah sentral pada selawatan sehingga hanya musiklah yang paling berperan menampilkan pembacaan syair dibandingkan dengan seni-seni lainnya. Seni vokal mendominasi kesenian ini karena hampir semua musik relijius Islami adalah musik vokal. Studi selawatan pernah dilakukan dalam berbagai latar belakang jenis kajian, yang di antaranya ialah kajian-kajian seni pertunjukan dari perspektif kultural, organologis, antropologi, sosiologi teater, dan musik Islami.

\section{Pembahasan}

\section{A. Perspektif Kultural Seni Pertunjukan Islami}

Pandangan kultural menempatkan selawatan sebagai bagian dari kebudayaan Jawa, yaitu sebuah vokal grup bernafaskan Islam. Di samping bentuk-bentuk seni pertunjukan lain yang sudah ada sebelumnya yang kemudian dipengaruhi Islam seperti mislanya seni gamelan dan wayang, selawatan termasuk bentuk pengungkapan baru dari jenis-jenis seni pertunjukan rakyat di Jawa yang diperkirakan lahir bersamaan dengan diperkenalkannya Islam (Sedyawati, 1995:117142). Walaupun tidak semua masyarakat pesantren melaksanakan tradisi selawatan, karena pesantren-pesantren di DIY berada di bawah organisasi, faham keagamaan, dan paradigma yang berbeda-beda, penelitian ini berasumsi bahwa hampir seluruh kesenian bernafaskan Islam di luar pesantren merupakan transformasi, baik langsung maupun tidak, dari jenis-jenis selawatan pesantren. Tradisi selawatan umumnya dilaksanakan oleh pesantren tradisional yang berafiliasi, baik secara langsung maupun tidak langsung dengan organisasi Islam terbesar di Indonesia, yaitu Nahdatul Ulama (NU).

Lagu selawatan dibeberapa tempat dinyanyikan secara solo dan diselang-seling dengan lantunan syair-syair relijius, di antara seruan panggilan salat (azan) dan ajakan dimulainya salat berjamaah (iqamat). Di luar waktu tersebut kelompok selawatan disajikan oleh pria dalam berbagai ritual adat dan pertemuan sosial relijius. Kini selawatan telah menjadi kosakata bahasa Indonesia yang pada dasarnya berarti pembacaan selawat yaitu doa bagi Nabi Muhammad SAW, keluarga dan para sahabatnya, yang dilakukan bersama-sama, dilagukan atau dilantunkan dengan gaya seni, dan kadang-kadang diiringi seperangkat rebana atau Terbang, serta beberapa instrumen lokal (Lihat Kamus Besar Bahasa Indonesia, 2008:1250).

Selawatan yang secara total menggunakan bahasa Arab, umumnya dipraktekan oleh masyarakat santri yang berada di pesantren tradisional dan sekitarnya, khususnya yang berbasis paham keagamaan NU. Musik vokal selawatan yang bersumber dari pesantren tersebut didasarkan atas syair-syair dalam kitab-kitab Islami klasik yang untuk membacanya diperlukan kopetensi 
bahasa Arab. Tuntutan tersebut bagi para santri dapat dimaklumi karena di samping sebagai pelajaran wajib, bahasa Arab juga digunakan untuk berkomunikasi sehari-hari. Bahasa Arab diperlukan sebagai alat dalam memahami Islam karena semua kitab-kitab yang dipelajari di pesantren, menggunakan bahasa Arab. Para lulusan pondok pesantren membawa tradisi mereka ke masyarakat sehingga berkembang sedemikian rupa, mulai dari lingkaran terdekat di sekitar pesantren hingga yang terjauh. Semakin jauh dari pengaruh pesantren maka semakin kental pula pengaruh tradisi lokal, mulai dari penggunaan bahasa hingga konten relijiusnya. Jenis-jenis selawatan yang dipertunjukkan dalam berbagai tradisi Jawa kini bertransformasi menjadi berbagai kesenian lokal dan menjadi bagian dari ritual Jawa yang lebih besar. Kitab-kitab al-Burdah dan Al-Barzanji adalah yang paling banyak dijadikan landasan penggubahan kesenian-kesenian tersebut (Ridwan, 1977: 260-261).

Sebagai seni pertunjukan Islami, selawatan ialah salah satu dari seni yang, jika ditinjau dari perspektif historis dan sosial-budaya, memiliki kaitan dengan Islam. Selawatan diperkirakan mulai ada sejak diperkenalkannya Islam pada bangsa Indonesia. Sri Hastanto (2002) meyakini bahwa berbagai musik Islami di seluruh kepulauan Indonesia tersebar seiring dengan penyebaran awal Islam (lihat Sedyawati, 2002:64). Termasuk jenisjenis musik yang tersebar saat itu ialah bentukbentuk yang sudah mengakar pada adat di pusatpusat penyebaran Islam. Santiswaran ialah contoh bentuk lama yang terpengaruh Islam dan salawat sebagai seni baru sejak awal diperkenalkannya Islam. Dalam melengkapi cakupan taksonomi trikotomis Sedyawati, ia menyinggung Sholawat Dulang sebagai gagasan baru budaya Minangkabau. Walaupun terkait dengan muatan-muatan Islam namun penggunaan dulang, adalah hal baru yang tentu saja bukan pengaruh Islam.

Informasi selawat menurut Hastanto (2002: 64-65) tersebut, mempertegas dikotomi antara salawat dan santiswaran. Salawat atau sholawat adalah seni pertunjukan rakyat Islami yang dengan berbagai variannya memiliki cakupan yang bersifat nasional sehingga dapat dijumpai pada kebudayaan-kebudayaan Indonesia lain di luar Jawa. Sementara itu santiswaran ialah produk budaya Jawa bermuatan Islam yang berasal gagasan para seniman Kraton Jawa Tengah. Upaya memperbandingkan di antara salawat dan santiswaran dalam proporsi yang seimbang, menimbulkan kesan bahwa artikel Hastanto cenderung bersifat "Jawa-Sentris." Bacaan-bacaan selawat, nasihat dan doa Islami yang terkandung di sela-sela penyajiannya, menegaskan bahwa pada dasarnya santiswaran adalah varian dari selawatan.

Philip Yampolsky (2002:66-67) berkeyakinan bahwa ciri khas selawatan ialah penggunaan rebana. Dalam pertunjukannya, jenis-jenis rebana dimainkan dalam jumlah yang bervariasi, dari dua hingga 30. Ensambel rebana yang disebut "rampak rebana" bukan merupakan musik instrumental namun termasuk tari-tarian pengiring syair-syair Islami yang dinyanyikan. Repertoar yang paling sering digunakan ialah syair Arab, Al-Barzanji, di samping syair-syair berbahasa Indonesia atau daerah. Dengan demikian ada dasarnya rampak rebana dengan berbagai variannya memiliki kesamaan dengan salawatan. Sebagaimana halnya santiswaran, rampak rebana juga dapat disebut sebagai varian selawatan.

\section{B. Perspektif Organologis Musik Jawa}

Penelitian selawatan di Jawa umumnya dilakukan oleh sarjana non-musik yang kajiannya mengarah pada tari-tarian, sejarah, dan proses sosialnya (Lihat Suharyoso, 1979; Iswantara, 2002; Rahman, 1978-79, Djoharnurani, 1994; dan Sunaryadi, eds, 1982). Dengan sendirinya informasi musik yang dihasilkan dari studistudi tersebut kurang signifikan. Selawatan yang melibatkan jenis-jenis seni pertunjukan nonmusik maupun yang melulu seni vokal, setidaknya menggunakan seperangkat instrumen Terbang sebagai pengiringnya, sehingga kadang juga disebut Terbangan yang muatan-muatan Islami, baik berupa doa-doa maupun kalimat-kalimat selawat.

Terbang diperkirakan diperkenalkan pedagang Islam dari Arab dan Afrika Utara. Tampaknya kesederhanaan dan bobot yang ringan pada rebana sehingga mudah dibawa, merupakan modal popularitas instrumen tersebut di Indonesia. Konon rebana dimainkan para musafir Arab yang senantiasa berpindah-pindah tempat (Kuntowijoyo et al., 1986-1987: 11). Pada masyarakat Jawa, beberapa instrumen rebana 
dimainkan secara ensambel sebagai pengiring grup vokal selawatan, dengan menambahkan instrumen-instrumen lokal seperti angklung, tambur, kentongan, dan ketipung.

Terbang ialah perkusi berbentuk silinder yang kerangkanya terbuat dari kayu dan salah satu sisinya direntangkan kulit. Di Cirebon terdapat lima ukuran Terbang yaitu: bibid (diameter: 45 $\mathrm{cm})$, kempyang $(40 \mathrm{~cm})$, darah $(36 \mathrm{~cm})$, induk $(30$ $\mathrm{cm})$, dan kempli $(26 \mathrm{~cm})$. Kelima jenis terbang tersebut dimainkan dalam ensambel bersamasama dengan empat buah genjring, yaitu terbang dengan beberapa pasang lempengan logam di seputar sisinya. Ensambel tersebut dipimpin oleh pemain genjring. Genjring bernada tinggi memainkan pola ritmik yang kompleks dan bervariasi dalam pola yang saling bersahutan. Bibid memegang peranan seperti gong dan dua terbang lainnya yang lebih kecil, dibawakan satu pemain dengan mnggunakan tongkat. Kempyang dan darah, memainkan ritmik reguler. Para pemain, yang umumnya terdiri dari kaum pria, memperkenalkan berbagai interpolasi vokal (senggakan) dan menyanyikan lagu-lagu secara unisono, dan kadang-kadang dengan penyanyi tambahan. Istilah 'terbang' juga digunakan di lampung, yaitu kendang berkepla ganda yang besar dan juga untuk sebuah kendang berkerangka dalam sebuah ensambel yang disebut kelenongan (Kartomi 1984:568).

Kunst (1973) memperkirakan bahwa terbang Jawa dan Sunda adalah peralihan di antara drum dan tambourin. Terbang berbentuk seperti mangkuk dengan rentangan selembar kulit lembu di atasnya. Di Banten, terdapat terbang ageung (diameter: 60-75 cm), terbang gembrung (25-30 $\mathrm{cm})$ yang rentangan kulitnya dikencangkan dengan tali rotan dan kayu pasak, dan terbang ketrimping $(25-35 \mathrm{~cm})$ yang dilengkapi dengan beberapa buah pasang lempengan logam di seputar sisinya. Di Sumedang, terbang yang tidak dilengkapi dengan lempengan logam disebut kempyang sedangkan yang menggunakan lempengan logam disebut Terbang gembung (Kunst, 1973:216-218). Fakta terkini mengenai Terbangan ialah dari seorang mahasiswi Jurusan Musik yang melakukan tugas lapangan di Kemandang, Gunungkidul, tahun 2003. Saat itu ia menjumpai sebuah kelompok terbangan dan tertarik untuk menelitinya sehingga pada tahun 2004 ia kembali ke daerah tersebut untuk pengambilan sampel (Rina, 2004). Sebagaimana telah ditemukan lebih dahulu oleh Kunst (1973) dan Kartomi (1984) instrumen utama ensambel selawatan yang dijumpainya juga meliputi: (1) Terbang dari jenis-jenis gong, kempul, kenting kecil, dan kenting besar; (2) dodog atau kendang, (3) sepasang kentongan, (4) sepasang kempyang, (5) sepasang angklung, dan (6) sebuah kecrek. Instrumen-instrumen yang berpasangan, masing-masing dimainkan satu orang.

Terbangan yang diterapkan dalam adat selametan Jawa mengandung aspek-aspek kebudayaan kuno non-Islam (Jawa yaitu animisme, dinamisme, Hindu dan Budha). Sinkretisme, yang dapat dijumpai pada adat Jawa, terbentuk setelah agama Islam masuk ke pulau Jawa, kirakira pada abad ke-16. Perpaduan berbagai unsur tradisi dalam Terbangan diperkirakan merupakan bagian dari dakwah Walisongo, khususnya Sunan Kalijaga, untuk menyebarkan Islam ke tengah masyarakat. Dengan tetap mengkombinasikan beberapa aspek sekuler dan spiritual dari berbagai kesenian tradisional, para Wali akhirmya berhasil menyisipkan ciri-ciri Islam ke dalam adat istiadat Jawa (Suryo et al., 1985:63).

\section{Perspektif Antropologis Pertunjukan Islami}

Tradisi pembacaan teks mawlid di pesantren pada mulanya bertransformasi menjadi selawatan Jawa, kemudian kepada berbagai seni pertunjukan rakyat. Dengan demikian kesenian-kesenian tersebut umumnya terinspirasi, baik langsung maupun tidak langsung, oleh Al-Barzanji, karya sastra Arab Islami yang memuat sejarah Nabi Muhammad SAW. Slawatan adalah suatu bentuk teater tradisional bernafaskan Islam yang penyajiannya menggunakan seperangkat rebana sebagai instrumen pengiring dan disebut slawat karena mengandung bacaan selawat. Slawat yang menyebar pada masyarakat Jawa di sekitar babad ke-16 ini memiliki fungsi dakwah penyebaran agama dan sekaligus juga sebagai tontonan atau hiburan (Ahimsa-Putra, 2000:72-73).

Pigeaud (1938) menempatkan selawatan dalam kelompok pembahasan pertunjukan tradisional di Yogyakarta dan Surakarta, yang didasarkan atas agama Islam. Dalam kebudayaan Islam Jawa kuno (antara akhir abad ke-19 dan awal abad ke20) terdapat perbedaan konotasi di antara slawat 
dan Slawatan. Dalam tradisi tingkeban atau kaul, slawat ialah sedekah uang di samping paket lauk pauk atau berkatan, sebagai pengganti upah penyajian prajanjen. Pemberian slawat pada ulama sebenarnya berkaitan dengan tradisi kematian seseorang. Salah satu definisi selawatan adalah sebagai berikut:

Dit zijn kleine geschenken in geld, bij verschillende godsdienstige plechtigheden of herdenkingen aan gasten van geestelijke stand gegeven, eigenlijk in het bijzonder behorende bij een begrafenis, als beloning voor het verrichten van sémbahjang's (salat, meervoud salawat), waarvan het loom bij God den overledene ten goede mode komen (Pigeaud, 1938:284).

Konotasi kata slawat dalam konteks selamatan Jawa akan sangat mengejutkan Muslim modern. Walaupun secara tidak langsung masih berkaitan dengan pengertian aslinya, namun maknanya sangat jauh sehingga terkesan aneh. Menurut terjemahan bebas Muhammad Husodo Pringgokusumo (1991), Kepala Rekso Pustoko, Perpustakaan Istana Mangkunegaran, adalah sebagai berikut:

Slawat adalah pemberian sedikit berupa uang, yang diberikan kepada para tamu pada berbagai upacara keagamaan, terutama kepada kaum ulama, yang sesungguuhnya hanya diberikan pada waktu ada suatu pemakaman, sebagai upah karena telah ikut dalam salat jenazah (salawat, adalah bentuk jamak dari: Salat); diharapkan upah tersebut menjadi amal baik dari orang yang meninggal di mata Tuhan (Pigeaud, 1991: 467).

Sementara itu, kata Slawatan berkaitan dengan pertunjukan keagamaan yang salah satunya ialah perjanjen sebagaimana disebutkan di atas. Berdasarkan anotasi pada gambar-gambar dalam buku kesenian rakyat yang bersifat keagamaan di Yogyakarta, Pigeaud mengutip definisi selawatan sebagai berikut:

"Slawatan is eigenlijk een opvoering van de godsdienstigen" (de "kerksen", tijang ingkang sami agami Islam), "maar nietgodsdienstigen laten soms ook wel eens zulke opvoeringen geven, hoewel selden. Slawatan heeft tot onderwerp een Arabisch verhaal : dit blijkt reeds uit de naam, want die is reeds Arabisch. Dit Arabische verhaal is de gedchiedenis van den Here Nabi Moehammad, van voor Zijn Geboorte af totdat Hij optrad asl Schutsheer de Moslims. Niet alle Slawatan-vertoningen verhalen dit gehele verhaal is eigenlijk slechts een verzameling van lofprijzingen, zegenbeden en eerbiedsbetuigingen (Pigeaud, 1938: 284).

Pengertian selawatan yang didasarkan atas anotasi yang terdapat pada salah satu bagian dari sebuah album berisi gambar-gambar yang mendeskripsikan Yogyakarta tersebut dalam terjemahan bebas Pringgokusumo (1991) adalah sebagai berikut:

"Selawatan sebenarnya adalah suatu pertunjukan dari orang Islam, namun yang bukan orang Islam kadang-kadang juga pernah mengadakannya, walaupun jarang. Pokok dari Slawatan adalah suatu cerita Arab; hal itu sudah tampak pada namanya, sebab itu adalah bahasa Arab. Cerita Arab ini adalah cerita Nabi Muhammad mulai dari sebelum kelahiran beliau sampai menjadi pelindung umat Islam. Tidak semua pertunjukan Slawatan mengambil seluruh cerita; biasanya hanya sebagian saja. Seluruh cerita itu sesungguhnya hanya kumpulan pujian, permohonan berkah dan juga pemberian kehormatan" (Pigeaud, 1991: 469).

Kecuali pada Slawatan Jawa, kata selawatan (Slawatan) tidak diterapkan untuk menyebut jenis-jenis seni pertunjukan Islami yang mengacu pada selawatan pesantren, melainkan dengan sebutan-sebutan lain yang khas misalnya perjanjen. Para pengamat kesenian rakyat jaman Belanda mengidentifikasi beberapa pertunjukan Slawatan di DIY (Pigeaud, 1991: 468-479). Selawatan dapat dibagi kepada dua macam yaitu, yang pertama ialah Muludan atau Slawatan Mulud yang seluruhnya menggunakan bahasa Arab; sedangkan yang kedua ialah Slawatan Jawa yang seluruhnya menggunakan bahasa Jawa; Di samping itu masih ada lagi yang disebut selawatan surabaya, yaitu yang penyajian bagian srokal-nya berbeda dari semua slawatan yang ada, yaitu tidak dilakukan dengan berdiri. Prajanjen yang didukung sepuluh pemain, termasuk pada kategori pertama. Di antara perbedaan-perbedaannya dengan Slawatan mulud adalah: (1) Tidak menggunakan 
instrumen pengiring, (2) dominasi teks Arab, (3) tidak ada peranan dalang, (4) pada bagian srokal, penyanyi mula-mula berdiri berderet dan kemudian terpecah menjadi dua kelompok, dan akhirnya bernyanyi secara bergantian. Pigeaud berasumsi bahwa prajanjen yang merupakan sinonim Slawatan, bukan tontonan rakyat melainkan cenderung sebagai kegiatan latihan keagamaan. Alasan-alasannya ialah: (1) dilakukan di kalangan santri, (2) sebagai menjemukan versi non-santri karena tidak menggunakan gamelan, (3) mengutamakan pembacaan teks Arab dengan diselingi nyanyian-nyanyian; Pemain prajanjen terdiri dari 4 bawa swara yang masing-masing menghadapi sebuah buku; dan enam orang singir (penyanyi) tanpa buku (Pigeaud, 1991: 467).

Selain dalang, fungsi lainnya dijabat oleh minimal dua orang. Dalang bertugas membacakan cerita (kanda) yang biasa disebut "tauladan" (tulada), dua orang bawa swara bertugas mendahului menyanyi pada saat dalang selesai membacakan riwayat atau cerita; enam orang wiyaga memainkan instrumen, dan membuat selingan (nyambungi) nyanyian yang dibawakan para bawa swara. Dalam menjelaskan jenis-jenis selawatan di luar prajanjen, di antaranya jumlah wiyaga lebih sedikit sehingga sisanya bertugas sebagai singir atau penyanyi koor. Lihat, misalnya dalam penjelasan slawatan sayid, yang didukung 3 singir dan 2 wiyaga; Sementara itu pada selawatan Rodad terdapat 3 singir dan 4 wiyaga; Yang terakhir, slawatan emprak didukung oleh 5 wiyaga yang sekaligus merangkap singir. Struktur selawatan yang tersusun dari tiga tahap tampaknya merupakan menjadi ciri yang mepersatukan sebagian besar varian-varian seni pertunjukan selawatan (Pigeaud, 1991: 469-470, 474-475, 477). Secara umum struktur penyajian selawatan terdiri dari tiga bagian yaitu tahap Awal, Srokal, dan penutup. Pada bagian awal isi teks terdiri dari bait-bait riwayat yang mengkisahkan dikisahkan saat Nabi Muhammad SAW masih berada dalam kandungan. Bagian srokal yang dilakukan sambil berdiri, mengkisahkan saat kelahiran Nabi. Diyakini bahwa Nabi dan para sahabatnya datang menyaksikan dan memberkahi orang-orangyang berselawat saat itu. Bagian penutup mengisahkan Nabi dari muda hingga saat meyebarkan Islam.

Berdasarkan interpretasi yang dibantu informan lokal dan anotasi dari album koleksi gambar- gambar tentang Yogyakarta, Pigeaud keseniankesenian selawatan selain prajanjen yang termasuk pertunjukan selawat. Yang pertama ialah Slawatan sayid, yaitu yang dibawakan oleh delapan orang yang terdiri dari para sayid dan ulama di bawah pimpinan seorang dalang yang memegang tasbih untuk mengingat jumlah pengulangan bacaanbacaan zikir. Selawatan ini didukung oleh tiga pemain Terbang, dua singir, seorang pembaca, dan seorang bawa swara; Mungkin yang dimaksud sayid dalam teks tersebut ialah apa yang kini disebut habib yaitu keturunan Arab yang diyakini adalah keturunan Nabi. Para sayid sangat dihormati. Masyarakat percaya bahwa dengan memuji atau menghormatinya maka ia akan dikasihi oleh Rasulullah. Di samping para sayid, Slawatan ini juga dibawakan oleh para ulama, dari wakyu isya hingga tengah malam, atau lebih pendek dari Slawatan mulud yang berlangsung hingga pukul tiga dini hari.

Bentuk selawatan yang kedua ialah Rodad, yang disertai dengan unsur pertunjukan dan pendidikan yang lebih banyak karena tidak semata-mata berbentuk vokal grup melainkan juga didukung oleh gerak-gerak teatrikal yang mirip tarian. Kesenian ini dibawakan oleh sepuluh orang pemain yang meliputi: Seorang dalang; sepasang bawa swara; 3 singir, dan 4 pemain yang terdiri dari 3 pemain genjring dan seorang pemain jedor. Para singir menyanyi sambil memegang kipas utuk membantu memperindah ornamentasi gerak tubuhnya. Dalam penyanjiannya dalang dan pemain jedor mengambil posisi terpisah sementara delapan orang lainnya duduk berjajar dua baris dan saling berhadap-hadapan kemudian bernyanyi secara bergantian. Setelah dalang membaca atau bercerita dari sebagian teks, bawa swara dari salah satu deret menyanyikan lagu-lagu dengan bahasa Arab, kemudian disusul oleh singir, dan barulah kemudian rebana-rebana genjring dimainkan. Urut-urutan ini dilakukan tiga kali, kemudian diulang lagi dengan isi teks yang berbeda. Gerakan Rodad diawali dengan gerakan-gerakan leher yang dilakukan sambil duduk (pacak gulu) kemudian berlutut (jengkleng) disertai dengan pacak gulu, bediri yang juga disertai pacak gulu, akhirnya para penari melakukan gerakan yang seolaholah sedang membopong bayi tanpa selendang; Konon gerakan ini meniru para bidadari yang membopong Nabi setelah beliau lahir (Pigeaud, 1991: 475). 
Menurut informan Pigeaud, di samping Rodad Jawa, terdapat juga Rodad Kojan yang berasal dari Koja, yaitu warga asing yang datang sebagai saudagar Islam di DIY. Susunan penyajian rodad Koja tidak banyak berbeda dengan rodad Jawa namun segala sesuatunya lebih sederhana (Pigeaud 1991: 477). Dari informasi yang didapatkan oleh Snouck Hurgronje, Pigeaud juga mendapatkan indikasi adanya pengaruh dua kesenian sejenis selawatan yang berasal dari Aceh, yaitu sadati dan rateb, terhadap Rodad. Kata Rodat memiliki kaitan erat dengan radat, yaitu salah satu dari dua orang yang bertindak sebagai pembawa cerita dalam kedua kesenian Aceh tersebut. Radat berasal dari kata Arab raddad yang berarti pengulang atau penjawab; biasanya terdapat dalam ritual zikir (Pigeaud 1991: 476). Boleh jadi Rodad di Mlangi berasal dari Koja karena tidak mendekati tarian lokal, dalam hal ini Jawa, melainkan cenderung menyerupai gerakan-gerakan seudati di Aceh namun jauh lebih sederhana sebagaimana terjadi pada gerakan-gerakan Rodad di Masjid Jami' Mlangi, Sleman, yang diketahui dari laporan observasi Indrawan (2010) yang dilakukan dari tahun 2008 hingga 2009.

Bentuk selawatan yang ketiga ialah Emprak. Keberadaan unsur-unsur keduniawian yang dominan pada Emprak, mendesak kesan-kesan keagamaannya. Kesenian ini dibawakan oleh 9 pemain yang terdiri dari seorang dalang, 3 orang bawa swara, dan 5 orang pemain instrumen yang sekaligus merangkap sebagai penyanyi. Instrumen musik yang digunakan untuk mengiringi seni pertunjukan ini meliputi sebuah Terbang dodog, sepasang Terbang ketuk dan kenong, sebuah kempul, dan sebuah gong. Dengan lagu-lagu yang diadopsi dari musik gamelan, para pemusik Emprak melakukan tarian dan bernyanyi bersamasama dengan dengan para bawa swara. Tugas bawa swara sebenarnya ialah menyambung cerita dalang dengan nyanyian dan tarian. Dalam penyajian Emprak, mula-mula para pemain duduk berderet lalu semuanya berdiri di hadapan sebuah meja dengan sesajen di atasnya, dan akhirnya bergerak maju dan mundur sebanyak lima kali. Setelah istirahat mereka kemudian membentuk lingkaran dan melakukan tarian sebanyak lima putaran dan akhirnya berbaris kembali seperti semula. Setiap kali lagu Arab berganti maka gerak taripun berubah. Dengan demikian dapat dikatakan bahwa
Emprak adalah selawatan yang paling mendekati tontonan keduniawian karena menyertakan tarian dan nyanyian (Pigeaud, 1991: 478-479).

\section{Perspektif Sosiologis Kajian Teater}

Jenis-jenis selawatan di luar pesantren memiliki populasi yang besar. Dari perspektif kajian teater, Suharyoso (2000) meyakini bahwa selawatan adalah salah satu dari lima jenis-jenis teater tradisional yang tersebar di Kabupaten Sleman, yaitu: (1) Jenis wayang, (2) jenis dramatari, (3) jenis Tayuban, (4) jenis Jatilan dan Reog, dan (5) jenis selawatan. Teater tradisional ialah seni pertunjukan yang bersumber pada tata kerakyatan, memiliki jiwa yang asli, dan lahir dari masyarakatnya secara spontan.

... teater tradisional Sleman didefinisikan sebagai seni pertunjukan yang terdapat di wilayah Kabupaten Sleman, yang berakar/ bersumber pada tata kehidupan kerakyatan, serta memiliki bentuk dan jiwa yang relatif masih "asli" dan lahir dari spontanitas kehidupan masyarakatnya (Suharyoso, 2000: 47).

Dalam kajian tersebut selawatan ditempatkan sebagai salah satu bentuk teater tradisional bernafaskan agama Islam yang diiringi oleh seperangkat instrumen Terbang. Penamaan selawatan tampaknya disebabkan oleh pengucapan kalimat-kalimat shalawat yang dinyanyikan, atau setidaknya menampilkan unsur-unsur shalawat dalam pertunjukannya. Repertoar selawatan merujuk kepada Kitab Al-Barzanji sebagai sumber utamanya. Selawatan yang berfungsi sebagai media dakwah Islam yang sekaligus juga adalah tontonan dan hiburan rakyat ini diperkirakan telah ada bersamaan dengan penyebaran Islam di Jawa sejak abad ke-16. Suharyoso (2000:71) setidaknya telah mengidentifikasi keberadaan duabelas varian selawatan yaitu: (1) Selawatan Maulud; (2) Selawatan Laras Madya; (3) Barzanji; (4) Rodad/ Selawatan Rodad; (5) Emprak; (6) Angguk; (7) Trengganan/ Kuntulan; (8) Peksi Moi; (9) nDolalak; (10) Badui; (11) Kobrasiswa; (12) Samroh/ Qosidahan.

Tiga selawatan pertama yang biasanya ditampilkan di rumah-rumah keluarga atau di serambi masjid, bukan merupakan tontonan umum. Kecuali Slawatan Barzanji yang bisa dibawakan oleh pria maupun wanita, dua yang 
lainnya hanya dilakukan oleh pria. Slawatan Barzanji didukung paling tidak oleh 25 orang, sementara dua yang lainnya oleh sekitar 15 hingga 30 orang dengan usia di antara 15 hingga 30 tahun. Sementara Laras Madya bersumber pada kitab Jawa, Wulang Reh, karya Sri Sunan Pakubuwono IV, Slawatan Maulud dan Barzanji bersumber pada kitab Al-Barzanji. Slawatan Maulud yang menggunakan terjemahan Jawa disebut Slawatan Jawa. Walaupun sebagian menggunakan bahasa Jawa namun varian-varian selawatan tersebut umumnya terikat oleh penggunaan bahasa Arab dan repertoar yang bersumber pada kitab Barzsanji, baik secara langsung maupun tak langsung. Kitab Wulangreh mengacu, atau paling tidak mengutip bagian-bagian Al-Barzanji yang diterjemahkan. Sementara itu syair-syair Islam, di antaranya juga mengutip bagian-bagian tertentu kitabAl-Barzanji. Ketiadaan aspek-aspek tari dan teater pada jenis-jenis selawatan ini memperkuat statusnya sebagai grup vokal tradisional.

Instrumen pengiring Slawatan Maulud ialah rebana: dodog dan beb (kendang), kempul, kenting, ketuk, dan gong. Pada Laras Madya digunakan tambahan isnstrumen lain yaitu peking atau saron berbilah dua, dan kentongan kecil. Sementara itu Barzanji dibawakan secara accapela. Di antara ketiganya, durasi Barzanji yang hanya dua jam, adalah yang terpendek dari kedua selawatan lainnya yang berdurasi 8 jam, dari pukul 8 atau 9 malam hingga dini hari keesokan harinya. Selain Samroh, bentuk-bentuk selawatan lainnya adalah kesenian rakyat berupa tarian masal yang semuanya didasarkan atas Kitab Barzanji, kecuali Slawatanselawatan Trengganan, nDolalak, dan Badui. Walaupun tidak disebutkan dari mana acuannya, selawat sebagai pengiring selawatan, baik pada Trengganan maupun nDolalak, dinyanyikan dalam bahasa Arab. Sementara itu Slawatan Badui didasarkan atas kitab Kotijah Badui yang di antaranya berisi budipekerti, kepahlawanan, dan kesatuan (Suharyoso, 2000: 71-74).

Selawatan yang repertoarnya didasarkan atas mawlid al-Barzanji, umumnya dinyanyikan dalam bahasa Arab. Walaupun demikian di antaranya ada yang menggunakan variasi dua hingga tiga kombinasi bahasa yaitu: Arab, Jawa, dan Indonesia. Instrumen pengiring bagi sebagian besar jenis Slawatan tersebut hampir sama dengan yang diterapkan pada Slawatan mawlid, namun beberapa di antaranya ada yang ditambahkan beberapa instrumen lain dan ada juga yang nyaris seluruh instrumennya berbeda. Walaupun demikian paling tidak instrumen pengiring Slawatan senantiasa melibatkan beberapa jenis Terbang. Samroh pada dasarnya mirip dengan Slawatan Maulud, namun repertoarnya lebih bebas dan merupakan tontonan umum yang merupakan bagian dari acara lain yang lebih besar (Suharyoso, 2000: 74-84).

Berdasarkan pendataan kelompok-kelompok kesenian yang dilakukan oleh pemerintah saat itu, populasi jenis-jenis varian selawatan di Sleman, sangat besar. Kenyataan tersebut menunjukkan jika di Sleman saja terdapat 306 kelompok jenis varian yang 202 di antaranya disebut Slawatan, maka jika ditotal dengan ketiga kabupaten DIY lainnya maka populasinya akan sangat besar. Jenis terbanyak di antara jenis-jenis selawatan tersebut ialah jenis Slawatan, yaitu sebanyak 202 kelompok, kemudian pada rangking di bawahnya secara berturut-turut ialah 28 Samroh, 16 Rodad, 15 Barzanji, 13 Kobrasiswa, 12 Laras Madya, dan 2 Angguk. Sedangkan sisanya mulai terancam kepunahannya karena masing-masing hanya tersisa satu kelompok saja, yaitu: 1 Trengganon di Seyegan, 1 Kuntulan di Minggir, 1 Peksimoi di Tempel, dan 1 nDolalak di Sleman. Dengan demikian kesenian-kesenian tersebut perlu mendapat perhatian, paling tidak agar segera didokumentasikan. Kecamatan yang memiliki satu jenis varian saja, yaitu jenis Slawatan, ialah Prambanan (Lihat Suharyoso, 2000; 87-103).

Dari aspek lokasi keberadaannya, kelompok jenis Slawatan yang terbanyak terdapat di Tempel, yaitu sejumlah 27 kelompok, kemudian Prambanan yang memiliki 22 kelompok. Selain itu secara bertahap jumlahnya menurun dari, Godean (19 kelompok), Seyegan (18 kelompok), Turi (18 kelompok), Moyudan (16 kelompok), Minggir (15 kelompok), Mlangi (13kelompok), Sleman (12 kelompok), Ngaglik (9 kelompok), Gamping (8 kelompok), Kalasan (7 kelompok), Ngeplak (7 kelompok), Pakem (7 kelompok), dan Depok (4 kelompok). Sementara Cangkringan tidak memiliki selawatan atau kesenian Islami lainnya dan Berbah juga demikian, kecuali hanya satu kelompok Samroh.

Banyaknya kelompok Slawatan tidak selalu seiring dengan jumlah jenis yang terdapat di suatu 
lokasi. Kecamatan yang memiki varian selawatan terbanyak ialah Tempel. Dari ketigabelas jenis varian, kecamatan ini memiliki 8 jenis, yaitu di atas kira-kira 50\% dari jumlah varian selawatan. Jenis selawatan yang tidak ada di kecamatan ini ialah: Rodad, Emprak, Kuntulan, dan Trengganon. Salah satu dari kedelapan jenis selawatan yang terancam kepunahannya ialah peksimoi, yaitu satu-satunya di Kabupaten Sleman, kemudian Angguk yang hanya tinggal dua kelompok, yaitu satu di Tempel dan satu lagi di Pakem. Di kecamatan lain rangking jumlah varian secara bertahap menurun, yaitu: Godean (7), Seyegan (6), Minggir (6), Turi (5), Ngaglik (4), Depok 4), Sleman (4), Kalasan (3), Mlati (3), Ngeplak (3), Gamping (3), Moyudan (3), Pakem (3), Prambanan (1), dan Berbah (1).

Korelasi di antara jenis Slawatan dan jumlah jenis-jenis varian selawatan di setiap kabupaten Sleman memberikangambaranyangunikmengenai persebaran seni pertunjukan Islami. Tempel yang memiliki jumlah kelompok selawatan terbanyak, yaitu 27, ternyata juga memiliki jenis-jenis varian yang terbanyak pula, yaitu 8 jenis. Selain selawatan, ketujuh yang lainnya ialah: 4 krlompok selawatan Laras Madya, 8 kelompok Barzanji, 1 Angguk, 1 Peksimoi, 4 Badui, 6 Kobrasiswa, dan 4 Samroh, sehingga keseluruhannya berjumlah 55 kelompok. Dengan demikian Tempel menempati posisi tertinggi dalam jumlah kelompokkelompok jenis selawatan, atau seni pertunjukan Islami, di seluruh Kabupaten Sleman. Di antara seni pertunjukan yang hampir punah dan perlu mendapat perhatian di kecamatan Tempel ialah Peksimoi; kesenian tersebut bukan hanya tinggal satu-satunya di Tempel tapi juga di seluruh Kabupaten Sleman.

Di Depok hanya teradapat 4 varian dan empat 4 kelompok Slawatan. Selain selawatan, yang jenis-jenis yang lainnya ialah 2 Rodad, 1 Badui, dan 1 Kobrasiswa. Sehubungan dengan itulah garis untuk jumlah selawatan dan untuk jumlah varian pada grafik di atas, bertemu pada satu titik. Fenomena yang serupa ternyata juga terdapat di kecamatan Berbah, yaitu hanya terdapat satu kelompok varian selawatan dan dengan sendirinya hanya ada satu jenis, yaitu Samroh. Jumlah jenis Slawatan yang banyak di antara varian-varian yang lain menunjukan bahwa jenis tersebut merupakan jenis utama sebagai ekspresi dari besarnya pengaruh Islam. Dengan demikian bukannya tidak mungkin bahwa varian-varian yang lain adalah hasil-hasil transformasi struktural dari jenis Slawatan yang merupakan jenis utama tersebut.

Dengan demikian persebaran selawatan di Gamping, yang di dalamnya terdapat dusun Mlangi yang terkenal dengan julukan "kampung santri” jumlah jenis variannya hanya tiga, yaitu Slawatan (8 kelompok), Emprak (1 kelompok), dan smaroh (2 kelompok). Walaupun jumlah kelompok jenis Slawatan hanya 8 kelompok, boleh jadi termasuk dari jenis Slawatan mulud, khususnya yang terdapat di Mlangi, Nogotirto. Sedikitnya jumlah kelompok selawatan pada masyarakat tertentu ternyata tidak dapat dijadikan ukuran bahwa pengaruh Islam di daerah tersebut tidak kuat karena keberadaan masyarakat Islam di Mlangi sangat kental pengaruh pesantrennya. Walaupun jumlah kelompok selawatannya sedikit boleh jadi memiliki kualitas religis yang tinggi jika dibandingkan dengan daerah yang memiliki kelompok selawatan yang banyak.

\section{Penutup}

Hasil penelitian tentang selawatan yang dilakukan oleh Pigeaud (1938) dan Suharyoso (2000), mengindikasikan terdapat kesamaan dalam penulisan ejaan peristilahan "selawatan" yang tampaknya diadaptasi dari pengucapan kata Jawa, yaitu Slawatan. Sebagian besar varian selawatan telah bertransformasi ke dalam berbagai kesenian Islami rakyat Jawa, sedangkan beberapa di antaranya masih dihadapi sebagai praktek keagamaan, seperti Barzanji atau Prejanjen. Satu jenis selawatan yang belum terungkap yaitu jenis selawatan yang teridentifikasi oleh Pigeaud sebagai Majemukan. Materi teks selawatan tersebut diambil dari teks Arab, kitab Syarfil Anam. Boleh jadi apa yang dimaksud dengan Majemukan oleh Pigeaud, mirip dengan selawatan pesantren yang sekarang masih dipraktekkan di pesantren tradisional DIY.

Keberadaan tradisi Majemukan nyaris luput dari perhatian para peneliti selawatan saat ini karena mungkin sudah dianggap punah. Hasil penelitian lapangan telah ditemukan fakta-fakta yang menyerupai kesenian yang diinformasikan Pigeaud sebagai Majemukan berikut kitab yang dijadikan sumber repertoarnya. Jenis selawatan tersebut ialah tradisi pembacaan syair-syair mawlid klasik. Walaupun tidak sama persis, 
secara umum Majemukan memiliki kesesuaian struktural dengan Selawatan pesantren. Sebagian besar dari keduabelas model selawatan yang ditemukan Suharyoso, termasuk juga beberapa bentuk selawatan teater yang ditemukan Iswantara (2002:16-54), hingga saat ini masih hidup dalam masyarakat Jawa. Apapun identifikasi berbagai perspektif yang dihasilkan, tak satupun mengelak bahwa selawatan, baik dalam kultur maupun subkultur pesantren, adalah seni pertunjukan musikal yang mengandung muatan-muatan relijius. Varietas bentuk-bentuk selawatan dalam masyarakat Islam tradisional di luar pesantren memiliki perbedaan yang sangat signifikan dan heterogen jika dibandingkan dengan jenis-jenis selawatan pesantren yang cenderung homogen.

\section{Kepustakaan}

Ahimsa-Putra, Heddy Shri (ed). 2000. Ketika Orang Jawa Nyeni. Yogyakarta: Galang Printika.

Departemen Pendidikan Nasional. 2008. Kamus Besar Bahasa Indonesia; Pusat Bahasa. Jakarta: PT Gramedia Pustaka Utama.

Djoharnurani, Sri. 1994. "Slawatan dalam Perspektif Koreografi; Sebuah Tinjauan Interkoreograf". Laporan Penelitian. Yogyakarta: Lembaga Penelitian ISI Yogyakarta.

Hastanto, Sri. 2002. "Salawat dan Santiswaran" dalam Edi Sedyawati Indonesia Heritage Vol. 8. Jakarta: Buku Antar Bangsa untuk Grolier International Inc., 64-65.

Indrawan, Andre. 2010. "Selawatan Pada Kultur dan Subkultur Pesantren Tradisional: Kajian Representasi Tradisi Musikal Relijius Mawlid dan Transformasinya di Daerah Istimewa Yogyakarta." Disertasi S3 Pengkajian Seni Pertunjukan dan Seni Rupa. Yogyakarta: Universitas Gadjah Mada.

Iswantara, Nur. 2002. "Keberadaan Seni Pertunjukan Tradisional Bernafaskan Keislaman di Daerah Istimewa Yogyakarta; Sebuah Kajian Sosiologi Seni." Laporan Penelitian Internal. Yogyakarta: Lembaga Penelitian ISI Yogyakarta.
Kunst, Jaap. 1973. Music in Java: Its History, its Theory, and Its Technique. The Hague: Martinus Nijhoff.

Kuntowijoyo, Kasniyah, Nanik dan Abubakar, Humam. 1986-1987. Tema Islam dalam Pertunjukan Rakyat Jawa: Kajian Aspek Sosial, Keagamaan, dan Kesenian. Yogyakarta: Departemen Pendidikan dan Kebudayaan Direktorat Jenderal Kebudayaan Proyek Penelitian dan Pengkajian Kebudayaan Nusantara, Javanologi.

Margaret J. Kartomi. 1984. "Terbang", entri dalam Stanley Sadie (ed), The New Grove Dictionary of Musical Instrument Vol. 3. London: Macmillan Press Limited.

Pigeaud, Th. 1938. Javaanse Volksvertoningen; Bijdrage tot de beschrijuing van land en volk. Batavia: Penerbitan Volkslectuur.

Rachman, Abdul. 1978-1979. "Tari-tarian Rakyat Jenis Slawatan di Daerah Kabupaten Bantul: Kesenian Slawatan Montro". Yogyakarta: Proyek Pengembangan Institut Kesenian Indonesia.

Rina Widyastuti. 2004. "Analisis Musikologis Kesenian Musikal Selawatan Terbangan di Desa Kemadang, Kecamatan Tanjungsari, Gunung Kidul, Daerah Istimewa Yogyakarta.” Skripsi S-1 Seni Musik. Yogyakarta: Jurusan Musik, FSP ISI Yogyakarta.

Sedyawati, Edi.1995. "Keislaman dalam Tari di Indonesia" dalam Jabrohim \& Berlian, Saudi (ed). 1995. Islam dan Kesenian. Yogyakarta: Majelis Kebudayaan Muhammadiyah \& Universitas Ahmad Dahlan.

Soedarsono (ed.), 1976. Mengenal Tari-tarian Rakyat di Daerah Istimewa Yogyakarta. Yogyakarta: Akademi Seni Tari Indonesia Yogyakarta. . 1977-1978. "Kamus Istilah Tari dan Karawitan Jawa.” Laporan Penelitian. Jakarta: Proyek Penelitian Bahasa dan Sastra Indonesia.

Sofwan, Ridin. 2002. Eksotisme Budaya Islam, Kasanah Peradaban dan Serambi Pesantren. Yogyakarta: Bukulaela.

Suharyoso. 1979. Penyebaran Teater Tradisional di Kabupaten Sleman. Yogyakarta: Rockefeller Foundation. 
Suharyoso. 2000. "Teater Tradisional di Sleman." Yogyakarta: Jenis dan Persebarannya," dalam Ahimsa-Putra, Heddy Shri (ed). Ketika Orang Jawa Nyeni. Yogyakarta: Galang Printika.

Suryo, Djoko; Soedarsono, R.M.; dan Sochiman, 1985. Gaya Hidup Masyarakat Jawa di Pedesaan: Pola Kehidupan Sosial-Ekonomi Dan
Budaya. Yogyakarta: Departemen Pendidikan dan Kebudayaan, Proyek Penelitian dan Pengkajian Nusantara.

Yampolsky, Philip. 2002. "Rampak Rebana" dalam Edi Sedyawati Indonesia Heritage Vol. 8. Jakarta: Buku Antar Bangsa untuk Grolier International Inc. 66-67. 